\title{
2. GESTALTDRAMA AS AN INTEGRATIVE PSYCHOTHERAPEUTIC APPROACH
}

Martin Dominik Polínek ${ }^{185}$

\begin{abstract}
The following text is an overview study which defines the basic phenomena and effective factors of Gestalt drama and outlines some of the researches carried out in this area by the author during recent years. Gestalt drama is the name of a specific psychotherapeutic approach applied by the author in his practice, which combines Gestalt therapy with expressive approaches (especially with dramatherapy, theatrotherapy and fairytale-therapy). Linking Gestalt therapy and expressive techniques results in a specific psychotherapeutic approach whose versatility and holistic conception makes it suitable not only for psychotherapy but also for self-development of people with special needs, as it has the potential to meet the higher psychological needs even when the lower needs are not sufficiently saturated. The article further presents the interpretation of the partial results of research focusing on the analysis of integration performance where gestaltdrama techniques have been applied. These performances resulted from one-day dramatherapy workshops with clients suffering from mental retardation and with clients with behavioural disorders. This includes the analysis of differences between dramatical expression within the above target groups.
\end{abstract}

Key words: Gestaltdrama, specific research, dramatherapy, theatrotherapy, fairytaletherapy, Gestalt therapy, basic psychological needs, integration performance

\section{Introduction}

The following text is an overview study which defines the basic phenomena and effective factors of Gestalt drama and outlines some of the researches carried out in this area by the author during recent years. Gestalt drama is the name of a specific psychotherapeutic approach applied by the author in his practice, which combines Gestalt therapy with expressive approaches (especially with dramatherapy, theatrotherapy and fairytale-therapy). This approach can be used not only for individuals with mental illness (possibly neurosis) but also in the self-development of people with psychosocial hazards or disruptions. Consequently, the author often works with children and adolescents with behavioural problems, adults with burnout, with homeless people, etc. (Cf. Rǔžička, 2013.) Dramatherapy consists in the application of theatrical means in therapeutic intervention. It is a therapeutic-formative discipline involving mainly work in groups and the theatrical means are used to influence group dynamics; it is focused rather symptomatically. (Cf. Valenta, 2001 and Müller, 2014.) Theatrotherapy can be defined as an expressive therapeutic-formative approach consisting in the overall preparation of the theatrical form and its subsequent presentation to the audience with a therapeutic-formative goal, whose participants are usually individuals with special needs. (Polínek in Müller, 2014.) Fairytale-therapy is a psychotherapeutic approach falling into expressive therapies which use fairytale imagery to achieve therapeutic targets. (Polínek in Müller, 2014) Gestalt therapy is a dialogical method that is based

\footnotetext{
${ }^{185}$ Assistant Ph.D., "Palacky University“ from Olomouc of Czech Republic, email: polinekm@seznam.cz
} 
on the phenomenological approach and awareness. In dialogue with the client, the therapist distinguishes perception, feeling and acting from mere interpretation. The basic objective is to make the client aware of what he/she does, how he/she does it and how it could be changed. In Gestalt therapy, we focus rather on the process (What is happening?) than on the content and interpretation (Why is this happening?). (Cf. Roubal, 2010, Yountef, 2009, Mackewn, 2004.)

\section{Effective principles of Gestalt drama}

While the expressive-formative approaches (dramatherapy, theatrotherapy and fairytale-therapy) provide very effective and safe methods and techniques for universal work with any client, the Gestalt psychotherapy offers models and constructs of how to understand the therapeutic process, how to approach a client or group. When applying all these approaches, we find an amount of common effective principles. The author believes that the definition and subsequent application of these principles can significantly streamline the therapeutic (or self-development) process.

\section{Holistic approach}

It means that the whole being is perceived and influenced at once (when accepting his/her mental, physical, rational, social and spiritual dimensions). Dramatic and literary arts are synthetic (comprised of many different interconnecting and influencing components - dance, visual arts, music, drama, creative writing $\ldots$ but also a contact with the audience, the stress before the premiere, etc.); Gestalt drama thus may affect the human subject from different angles, in different ways, it can act simultaneously in various areas (Polínek in Hutyrová, 2014). The basic thesis of Gestalt therapy is also a holistic approach. F. Perls (1996, p. 13), the founder of Gestalt therapy, says: "First and foremost, we have to take into account that the body always works as a whole. We do not have liver or heart. We are the liver and heart and brain, etc. ... We are not simply the sum of individual parts but a coordinated whole ..."

\section{Projections, metaphor - a safe distance}

Already Aristotle, in his Poetics, describes some ability of drama to cleanse the viewer (catharsis) by arousing grief (eleos) and horror (phobos) (Gronemeyer, 2004); therefore, he also presents a kind of therapeutic effect of the theatre. Aristotle sees the mechanism of catharsis evoked by the tragedy as follows: "Through pity and fear, the tragedy purges those feelings". "The story of Romeo and Juliet does not affect us due to those two lovers from distant Verona, immemorial times and unknown society, but due to the fact that these two theatrical characters allow us to project ... and experience our own relationships, own loves, generational conflicts, etc. ... all of this in a safe environment (- after all, it does not relate to us, it is just a theatre)" (Polínek in Hutyrová, 2014, p. 155). S. Jennings, founder of the dramatherapy, says that "the paradox of dramatherapy lies in the fact that inducing distance brings us closer ... In the famous story, everyone finally finds his/her own story." (Hickson, 2000, p. 22). With regard to psychotherapy, the basic effective factor of fairytales is their imaginativeness and symbolism which carries good 
potential for secure personal projections. (Polínek in Müller, 2014). Vačkov (2011) states that the fairytale-therapy can work with different types of texts; these texts, however, must be based on a metaphor acting as a "mirror" that helps us to see ourselves from a different perspective, and also as a "crystal" through which the client can watch the surroundings from an unexpected side, which gives him/her the opportunity to create other relationships. Similar means can also be found in the Gestalt therapy. Mackewn (2004, p. 149) suggests that metaphors can help clients to "circumvent or overcome their inner blocks or obstacles and express themselves authentically". In the context of a treatise on the safe expression of relationships in the group, Zinker (2004, p. 156) states that "imagination could have the advantage of avoiding direct confrontation.... because the combination of abstract concepts is somewhat distant from uninviting and threatening reality of group egocentricity."

\section{"Now and here" and the emphasis on action}

Rising of self-awareness in the present moment is the basic principle of Gestalt therapy. Theatre, or dramatherapy, is based on a similar principle. E.g. Johnson's school of "developmental changes", one of the major streams of dramatherapy, lies in the sheer spontaneous improvisation stemming from awareness of "here and now" (Valenta 2001). Zinker (2004, p. 140) speaks similarly about a group experiment, which he describes as a creative event "growing from the group experience. This event is not predetermined and its outcome cannot be predicted." The emphasis on action is also a characteristic feature of both dramatherapy and Gestalt approach. Many words are often counterproductive in dramatic creation; in the dramatization, far better results can be reached by improvisation (i.e. unprepared actions) on a given subject than by intellectual verbalization "about the given subject". This also refers to the above principle of "here and now". Through the action, we can be in close contact with the role, the story and situation - when experiencing (playing) the role, the story and situation actually, here and now. We allow the reality to affect us not only at the rational level but also at the emotional level, at the level of fantasy. (Polínek, 2012) Gestalt therapy addresses the same. For example, this can be found in the Perls' description of Gestalt work with dreams: "Instead of analyzing and further dissection of a dream, we want to return it back to life. A way to return the dream to life is to live it again, as if it is happening now. Instead of telling the dream as a story from the past, try to play it in the present so that it becomes part of yourself and you will be fully in. (Perls, 1996, p. 76). Fairytale-therapy also accentuates the above-named principles. Therefore, fairytale analysis is not a therapist's interpretation; its sense is produced in dialogue with the client (Sakovič, 2012). The basic approach of fairytale-therapy is helping. "It is important to understand the scenario of human life and blind leads into which one is taken; but even more important for human beings is to know how to get out from these impasses to their naturalness - to meaningful and joyful life, repleted with contacts and a feeling of freedom." (Черняева, 2007, p. 7). 


\section{Creative principle}

The basic and most important principle seems to be the creative principle which could be identified with the fulfilment of the highest psychological need, i.e. the meta-need of self-fulfilment as called by Maslow. This is the need which is the pinnacle of human existence, and which is often not fulfilled in psychotherapeutic clients. "Creativity is a celebration of own nobleness, awareness of the fact that everything is possible. ... It is the fulfilment of what is urgent, what wants to be named. ... It is also a social act - the person shares this celebration, this affirmation of fully lived life with others," (Zinker, 2004, p. 1). In homeless clients, for example, where the lowest psychological needs (safety, structure) or even basic physiological needs are not fulfilled, it is very difficult to appeal to the highest needs (self-realization) which are a source of internal motivation to change. Researches in theatrotherapy and theory of Gestalt psychotherapy show that the encouragement of creativity can saturate the highest needs (at least partly) and thus increase, for example, the motivation to change in homeless clients. (Cf. Polínek, 2007; Zinker, 2004).

\section{Gestalt drama and fulfilment of basic psychological needs}

The following summary is based on long-term international researches conducted by the author in recent years. In this paper, we present just a summary of these researches which examined groups of clients treated with methods of Gestalt drama. Frequently, the basic psychological needs of individuals in these groups were not saturated. During the research, the subjective perception of the level of fulfilment of basic psychological needs in real life and Gestalt drama was compared. The research provides the following results (Cf. Polínek in Hutyrová, 2014; Polínek in Friedlová, Lečbych, 2014):

- Gestalt drama saturates the basic psychological need for security, even in the early stages of the process. The subjective perception of the level of saturation of this need in real life and in playing roles varies significantly; within the roles, the need is perceived as more saturated. Saturation of this need grows in proportion to time.

- The most emphasised feature is unsaturation of the need for external appreciation, which even deepens in role playing (this may have a positive implication for future therapeutic work, in increasing awareness and paradoxical theory of change (cf. Mackew, 2004) as well as in preventing counterproductive cohesiveness within the group.).

- In the Gestalt-drama therapeutic work, we observe a high level of selfappreciation and self-confidence. This fact may correspond to the assumption that paratheatrical way of working has the potential to accentuate the authentic creative process, which can have a positive impact on the healthy development of personality despite unsaturation of some lower needs. I.e. Gestalt drama helps in saturating self-appreciation despite the lack of external appreciation.

- Compared to the subjective perception of the level of saturation of psychological needs in real life, Gestalt drama improves this perception with regard to all the basic psychological needs. 


\section{Specifics of integration performance}

The following test is based on research of the recording of performances resulting from integration dramatherapy workshops, organized annually by the Elementary Art School Zlín. The objective of the workshops is to link individuals with problematic behaviour with individuals with mental disorders through creative drama work under the direction of experienced dramatherapists. The goal of the analysis was to focus on verbal and non-verbal expressions of the actors - clients and on their mutual cooperation. This includes some of the components of the bio-psycho-social model and the rational, emotional and physical components of an individual. The basic intention was therefore to verify to what extent the drama forms are holistic (involving all levels of one's personality). Three dramatherapy forms were selected as a sample, resulting from one of the described workshops. By intention we selected a sample from a period of time when the workshops have already been organized for several years and the dramatherapy techniques had stabilized. These are three about tenminute-long performances, performed by a mixed group of actors (individuals with mental disorders and with behavioural problems). The performances represented the outcome of an all-day dramatherapy process. The frequency of the following categories were studied in 10-second sequences: 1 . word(s) to self, 2. word(s) to a drama partner, 3. word(s) to audience, 4. interjection to self, 5 . interjection to a drama partner, 6 . interjection to audience, 7. movement alone, 8 . movement (stimulus/reaction) to a drama partner, 9. movement (stimulus/reaction) to audience. While categories 1-3 focused on the verbal component (or cognitive expression), categories 4-6 focused on the emotional component of the expression and categories 7-9 focused on the non-verbal (physical) component. Categories 2, 3, 5, 6, 8, 9 represented the social contact. Data acquired through frequency-sequence analysis were also compared as part of two different target groups in order to define the differences in dramatherapy expression between the actors with behavioural problems and actors with mental disorders. A statistical analysis of the probability of occurrence of individual categories was carried out. Partial results have been graphically represented by graphs (Polínek in Hutyrová, 2015): $\quad$ Graph No.1

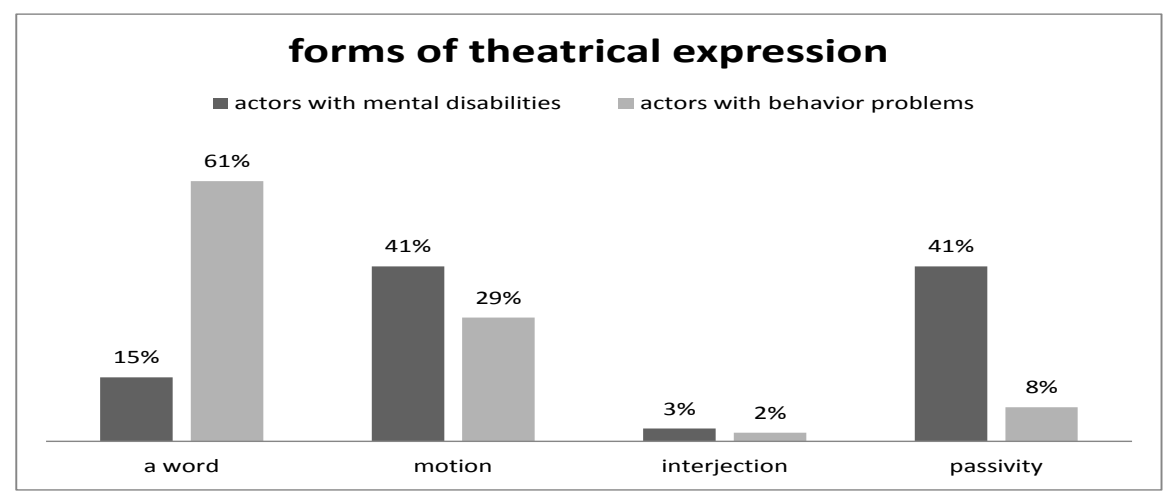

Graph No.1 represents the frequency of individual types of drama expressions in both groups of actors. From the graph it follows that verbal expression prevails over non-verbal in actors with behavioural problems and the 
opposite is true in actors with mental disorders. Moreover, the actors with mental disorders remain without activities over longer periods of time during the performance. From subsequent results it appears that both groups have a significant prevalence of stage interaction, with the same ratio to the verbal expression (3:2), making it clear that both groups are capable of equal social contact. The non-verbal component of interaction is more balanced in actors with mental disorders, which is more dramatically effective compared to actors with problematic behaviour, where the level of non-verbal interaction is lower. Moreover, the actors rarely use interjections to express emotions. (This may be caused by "theatrical inexperience" resulting from only short drama preparation during the workshop). On the basis of these specifics, it appears that highquality (artistically effective) drama performance is not adversely affected by reduced mental abilities and with respect to the balance between verbal and nonverbal component of the performance, it may even be very beneficial to combine actors with various specific needs. This is in line with global trends in the field (see Попова, 2013). This scientifically confirms the benefit of inclusivity not only for individuals with specific needs, but also for the audience and for the quality of the theatrical performance.

\section{An example of the structure of Gestalt-drama therapeutic session}

The following procedure illustrates the interconnection of gestalt approach (especially the phenomenon of "here and now") with dramatherapy (i.e. with a holistic approach) and fairytale-therapy within a session of self-development group that is already in the executive development phase. (More closely - see Truckman in Meulmeester, 2010, p. 114).

1. The therapist says that he/she does not bring any topic, and that he/she wants to share topics of the group members.

2. The therapist prompts them to realize their first response to the previous communication and put it aside.

3. Clients show by hands to what extent they have formulated their themes right now. (The higher the hand, the more simulated is the topic.)

4. The clients perceive their actual physical, emotional and rational reactions.

5. Based on the prior awareness, they create a statue from their body.

6 . They experiment with the movement of the statue; later they add sound and walking in space. Initially, they walk for themselves; afterwards, they perceive others and eventually meet with others in short improvised etudes.

7. Finally, all of them create a sculpture where each member of the group should express his/her own feelings in connection with the prior mutual contacting.

8. The clients leave their roles, symbolically put off the "unwanted" in an imaginary box and "replay" all previous events in the idea as a short film.

9. On the basis of the previous, they write a short "fairy tale". Stories can be shared by the group in the form of simple reading but also through their common dramatization. (Cf. Vačkov, 2011)

10. They attempt to realize the possible parallels with events within the session and actual life context. 
11. They verbally reflect within the group; the therapist captures the emerging themes as a possible material for future sessions.

\section{Conclusions}

Linking Gestalt therapy and expressive techniques results in a specific psychotherapeutic approach whose versatility and holistic conception makes it suitable not only for psychotherapy but also for self-development of people with special needs, as it has the potential to meet the higher psychological needs even when the lower needs are not sufficiently saturated. This premise, indicated by the author as Gestalt-drama therapeutic accentuation of the Maslow exception (Polínek in Hutyrová, 2014, p. 158), is a potent factor which can significantly contribute to improving the quality of life, especially in individuals with psychosocial hazards and disruptions.

\section{References}

1. Gronemeyer, A. (2004). Divadlo. Brno: Computer Press

2. Hickson,A. (2000). Dramatické a akční hry. Praha: Portál, 2000

3. Mackewn, J. (2004). Gestalt psychoterapie. Praha: Portál, 2004

4. Meulmeester, F. (2010). Změna přijde, když se zastavišs. Dobříš: Drvoštěp

5. Müller, O. (2014). Terapie ve speciální pedagogice. Praha: Grada

6. Perls, F.S. (1996). Gestalt terapie doslova. Olomouc: Votobia

7. Polínek, M.,D. (2007). Tetroterapeutické trendy v systému péče o osoby se specifickými potřebami v České republice. Olomouc. Disertační práce na Pedagogické fakultě Univerzity Palackého v Olomouci na katedře speciální pedagogiky. Vedoucí práce Milan Valenta

8. Polínek, M. D. (2012). Gestalt př́istup v teatroterapii . Arteterapie, 29, 122-125

9. Polínek, M. D. (2014). Diagnosticko-saturační potenciál metod expresivních terapií v oblasti základních psychických potřeb. In FIEDLOVÁ, M., LEČBYCH, M. Společný prostor/Common Space 2014: Sbornik př́spěvki̊. Olomouc: Univerzita Palackého v Olomouci, s. $230-242$

10. Polínek, M. D. (2014). Gestaltdrama: zvýšení uvědomnění a základní psychické potřeby. In Hutyrová, M. a kol. Jinakost ve speciálněpedagogickém kontextu. Olomouc: Univerzita Palackého v Olomouci, s. 153-159

11. Polínek, M. D. (2015 Specifika teatroterapeutických představení In Hutyrová, M. Perspektivy speciální pedagogiky. Olomouc: Univerzita Palackého v Olomouci

12. Růžička, M. (2013). Krizová intervence pro speciální pedagogy. Olomouc: Univerzita Palackého v Olomouci

13. Roubal, J.; Vybíral, Z. (2010). Současná psychoterapie. Praha: Portál

14. Valenta, M. (2001). Dramaterapie. Praha: Portál

15. Yontef, G. M. (2009) Gestalterapie: Uvédomování, dialog a proces. Praha: Triton

16. Zinker, J. (2004). Tvưrči proces v Gestalt terapii. Brno: ERA

17. Вачков, И.В. (2011) Введение в сказкотерапию. Москва: Генезис

18. Черняева, С.А. (2007). Психотерапевтические сказки и игры. СанктПетербург: Речь

19. Сакович, Н.А. (2007). Практика сказкотерапии. Санкт-Петербург: Речь. ISBN 5-9268-0383-7

20. Попова, Н., Т. (2013). Актуальные проблемы психологической реабилитации лиц с ограниченными возможностями здоровья: сборник научных статей. Moskva: Московский городской психолого-педагогический университет 